\title{
RESPONSE OF POPULUS ALBA, L. TRANSPLANTS TO COMPOST, BIOFERTILIZERS AND MINERAL NPK FERTILIZATION
}

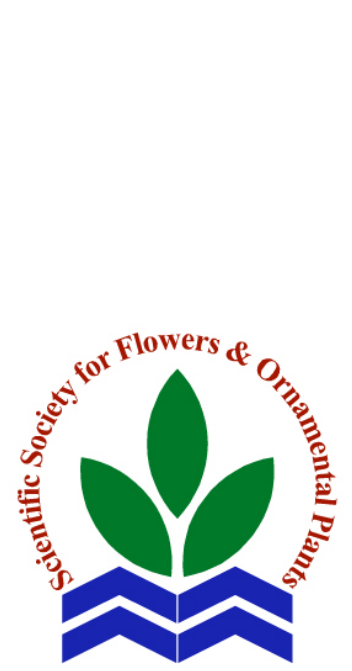

Scientific J. Flowers \& Ornamental Plants, 2(1):51-65 (2015).

Received:

$4 / 12 / 2014$

Revised by:

Prof. Dr. E.S. Nofal, Kafr El-Sheikh Univ.

Prof. Dr. A.Z. Sarhan, Cairo Univ.

\author{
M.A.H. Abdou ${ }^{*}$ and T.I.E. Ibrahim ${ }^{* *}$ \\ * Horticulture Dept., Fac. Agric., Minia Univ., Egypt. \\ ** Ministry of Agriculture, Egypt.
}

\begin{abstract}
This investigation was conducted to investigate the response of Populus alba transplants to compost fertilization at four levels and Bio. and/or mineral NPK treatments (control, phosphorein, effective microorganisms (E.M.), phosphorein + effective microorganisms, a mixture of Bio. (phosphorein + E.M.) $+75 \%$ NPK and mineral NPK, full dose) on vegetative and root growth parameters and some chemical constituents.

The obtained results indicated that, transplant height, stem diameter, whole transplant fresh and dry weights, main root length, fresh and dry weights of roots, as well as, chemical constituents including total chlorophylls, percentages of N, P and K were gradually
\end{abstract} increased by increasing the levels of compost fertilizer.

Biofertilizers and/or mineral NPK fertilization treatments significantly increased all the previous parameters. Bio. $+75 \%$ NPK dose followed by mineral NPK (full dose) treatments were the most effective in this concern.

The interaction between compost and Bio. and/or mineral NPK fertilization treatments was significant for vegetative and root growth parameters with the highest values for vegetative and root growth traits being obtained due to either compost fertilizer in combination with Bio. $+75 \%$ NPK dose or with mineral NPK (full dose).

Key words: Populus alba, compost fertilization, biofertilizers, phosphorein, E.M., NPK, vegetative growth, chemical constituents.

\section{INTRODUCTION}

Poplar is one of the best fast-growing trees in the world (Liu et al., 2009). Poplar is a member of Salicaceae family, which includes several species and is distributed extensively in the world (Bradshaw et al., 2007). Poplars provide a wide range of wood products including industrial roundwood, pulp and paper, reconstituted boards, plywood, veneer, sawn timber, packing crates, boxes, pallets and furniture. Poplars also produce young branches and foliage for use as an alternative sheep fodder. Poplars have a positive role in preserving the environment, they are used as shelterbelts, windbreak against wind, soil erosion control, carbon sequestration, climate change mitigation, agroforestry and protection of water, crops, livestock and dwellings (Ball et al., 2005).

Organic materials are added to soils to improve their physical and chemical properties of macro and micro elements, amino acids, organic acids, sugars and organic matter (Abo El-Fadl et al., 1968). Also, they are considered useful substrate for several beneficial microorganisms and water holding capacity. Tisdale et al. (1985); Hart and Nguyen (1994) ; Gangoo et al. (1997); Ali et al. (2002) and Ahmed et al. (2006) on 
poplars found that organic manures treatment led to increase vegetative and root growth traits, as well as, pigments and N, P and $\mathrm{K}$ percentages in the leaves.

Biofertilizers are considered to be low cost, ecofriendly and renewable sources of plant nutrients more than supplementing chemical fertilizers in sustainable agricultural systems. In this respect, Ahmed et al. (2005) on Populus nigra transplants concluded that biofertilizer treatments significantly increased stem length and diameter, number of branches, fresh and dry weights of transplants, root length and fresh and dry weights and chemical constituents (pigments and NPK elements) compared to control. Similar results were reported by Rajeshkumar et al. (2009) on Melia azedarach; Abdou and Ashour (2012) on jojoba seedlings ; Umashankar et al. (2012) on Grevillea robusta and El-Quesni et al. (2013) on Jatropha curcas.

Many authors studied the effects of NPK fertilization on poplar plants as Zabek (1995), Kohan et al. (2000), Ali et al. (2002), Ahmed et al. (2005), Coleman et al. (2006) and Tripathi et al. (2012) who found that the treatments of mineral NPK fertilizer increased the vegetative growth characters. Amin (2013) on Pinus radiata and Robinia pseudoacacia transplants concluded that mineral NPK fertilizers increased plant height, root length, stem diameter, leaf area and fresh and dry weight of shoots and roots, as well as, N, P and $\mathrm{K}$ percentages in the two plants under investigation.

Poplar can grow well under arid area, however, fertilization needs to be investigated under the Egyptian conditions.

This work aimed to investigate the response of Populus alba transplants grown in sandy soil to organic, biofertilizers and mineral fertilization in order to enhance and improve their characteristics.

\section{MATERIALS AND METHODS}

This investigation was carried out during the two successive seasons of 2012 and 2013 at the Nursery of Ornamental Plants, Faculty of Agriculture, Minia University to figure out the response of Populus alba transplants grown in sandy soil to organic and Bio. and/or mineral fertilization treatments.

Cuttings of Populus alba were obtained from Mallawy Agricultural Research Station, Minia Governorate, Egypt. Cuttings were planted on March $10^{\text {th }}$ for both seasons in containers $(25 \times 25 \times 35 \mathrm{~cm})$ as each was filled with $21 \mathrm{~kg}$ of sandy soil. Each container contained 3 cuttings and transplants were thinned to one transplant/container after one month from planting date. Physical and chemical properties of the soil used are listed in Table (a).

The split plot design with three replicates containing 4 transplants per replicate was followed in this experiment. The four levels of compost treatments were considered as main plots (A) and the six biofertilizers and/or mineral NPK fertilization treatments occupied the subplots (B). Therefore, the interaction treatments $(\mathrm{A} \times \mathrm{B})$ were 24 treatments. The four levels of compost were compost $_{0}$ (without compost as control), compost ${ }_{1}$ (250 $\mathrm{g} /$ container), compost $_{2}$ (500 g/container) and compost $_{3}(750 \mathrm{~g} /$ container $)$. The used compost called (compost El-Neel) was obtained from the Egyptian Co. for Solid Waste Utilization, New Minia City. Compost was added during filling of the container. Physical and chemical properties of the used compost are shown in Table (b).

The biofertilizers and/or mineral NPK fertilization treatments were as follows: 1- without any fertilizers (control), 2phosphorein at $5 \mathrm{~g}$ /container, 3- Effective microorganism (E.M.) at $50 \mathrm{ml} /$ container (1 $\mathrm{ml}=10^{7}$ cells $)$ 4- phosphorein + E.M., 5Bio. (phos. + E.M.) $+75 \%$ NPK and 6$100 \%$ NPK as recommended dose. Fresh and active two biofertilizers namely, phosphorein (P-dissolving bacteria) and E.M. (containing photosynthetic bacteria + lactic acid + yeasts) were applied either separately or in a mixture at three times at one month interval starting 45 days after planting (April $24^{\text {th }}$ for the first and second seasons). Biofertilizers 
Table a. Physical and chemical properties of the experimental soil.

\begin{tabular}{|c|c|c|}
\hline \multirow{2}{*}{ Character } & \multicolumn{2}{|c|}{ Value } \\
\hline & 2012 & 2013 \\
\hline$\overline{\text { Sand \% }}$ & 89.00 & 90.00 \\
\hline Silt $\%$ & 8.30 & 7.40 \\
\hline Clay $\%$ & 2.70 & 2.60 \\
\hline Texture & Sandy & Sandy \\
\hline $\mathrm{CaCO}_{3} \%$ & 14.45 & 14.83 \\
\hline pH $(1: 2.5)$ & 8.14 & 8.15 \\
\hline Organic matter \% & 0.05 & 0.04 \\
\hline E. C. (m mhos/cm) & 1.09 & 1.11 \\
\hline Total N \% & 0.02 & 0.02 \\
\hline Available P \% & 3.34 & 3.51 \\
\hline Extr. K (mg/100 g soil) & 0.90 & 1.01 \\
\hline $\mathrm{Fe}$ & 1.12 & 1.19 \\
\hline DTPA & 0.40 & 0.42 \\
\hline Ext.ppm & 0.35 & 0.31 \\
\hline Mn & 0.61 & 0.70 \\
\hline
\end{tabular}

Table b. Physical and chemical properties of the used compost.

\begin{tabular}{lclc}
\hline Properties & Value & Properties & Value \\
\hline Dry weight of 1 & $450 \mathrm{~kg}$ & NaCl (\%) & $1.1-1.75$ \\
Fresh weight of 1 & $650-700$ & Total P (\%) & $0.5-0.75$ \\
Moisture (\%) & $25-30$ & Total K (\%) & $0.8-1.0$ \\
pH 1:10 & $7.5-8$ & Fe (ppm) & $150-200$ \\
E.C. (m & $2-4$ & Mn (ppm) & 25.56 \\
Total N (\%) & $1-1.4$ & Cu (ppm) & $75-150$ \\
Org. matter (\%) & $32-34$ & Zn (ppm) & $150-225$ \\
Org. carbon (\%) & $18.5-19.7$ & \\
C/N ratio & $18.5-14.1$ & \\
\hline
\end{tabular}

were added to the soil around each transplant and then they were irrigated immediately.

The recommended mineral NPK fertilization was $3 \mathrm{~g} /$ container of ammonium sulphate $(20.6 \% \mathrm{~N})+4 \mathrm{~g} /$ container of calcium superphosphate $\left(15.5 \% \quad \mathrm{P}_{2} \mathrm{O}_{5}\right)+2$ $\mathrm{g} /$ container of potassium sulphate $(48 \%$ $\mathrm{K}_{2} \mathrm{O}$ ) El-Kayal (1996), while $75 \%$ NPK were $2.25+3+1.5$, respectively. The amounts of mineral NK fertilizers were divided into three equal batches and added at one month interval, starting April $30^{\text {th }}$ in both seasons, while all amounts of $\mathrm{P}$ were added with the first dose of NK. All other agricultural practices were carried out as usual in the region in the two experimental seasons.

The following data were recorded at the last week of October for the two experimental seasons:
1- Vegetative growth characters: - transplant height $(\mathrm{cm})$, stem diameter $(\mathrm{mm})$, whole fresh and dry weights $(\mathrm{g})$.

2- Root growth characters: - main root length $(\mathrm{cm})$, fresh and dry weights of roots.

3- Determination of some chemical constituents: - total chlorophylls $(\mathrm{mg} / \mathrm{g}$ f.w.) were determined in the fresh leaves samples using the method described by Moran (1982), the percentages of N, P and $\mathrm{K}$ in the dry leaves were estimated according to Page et al. (1982).

All of the obtained data were subjected to the statistical analysis of variance using MSTAT-C (1986). L.S.D. test at 0.05 was used to compare the average means of treatments.

\section{RESULTS AND DISCUSSION}

\section{1- Vegetative growth characters:}

Data presented in Tables (1 and 2) showed that transplant height, stem diameter, whole fresh and dry weights/transplant were significantly increased in both seasons due to the use of compost 1 , compost 2 and compost 3 fertilization in comparison with those of inorganic fertilizer (compost ${ }_{0}$ ). Moreover, the increase was gradual by the gradual increase in compost levels. The increase in vegetative growth traits due to the low, medium and high level of compost over the control reached 19.31, 28.22 and $40.12 \%$ for transplant height, 3.51, 7.81 and $21.29 \%$ for stem diameter, $30.59,50.76$ and $65.65 \%$ for whole plant fresh weight and 35.94, 59.53 and $79.65 \%$ for whole plant dry weight, respectively, in the first season. The results in the second season took a similar trend. Similar, results were found by Hart and Nguyen (1994); Gangoo et al. (1997); Ali et al. (2002) and Ahmed et al. (2006) on poplars.

The stimulatory effect of compost treatments on vegetative growth traits may be due to organic manure which gave availability of most nutrients. Such stimulation of the uptake of nutrients leads to enhancing the biosynthesis of organic foods 
M.A.H. Abdou and T.I.E. Ibrahim

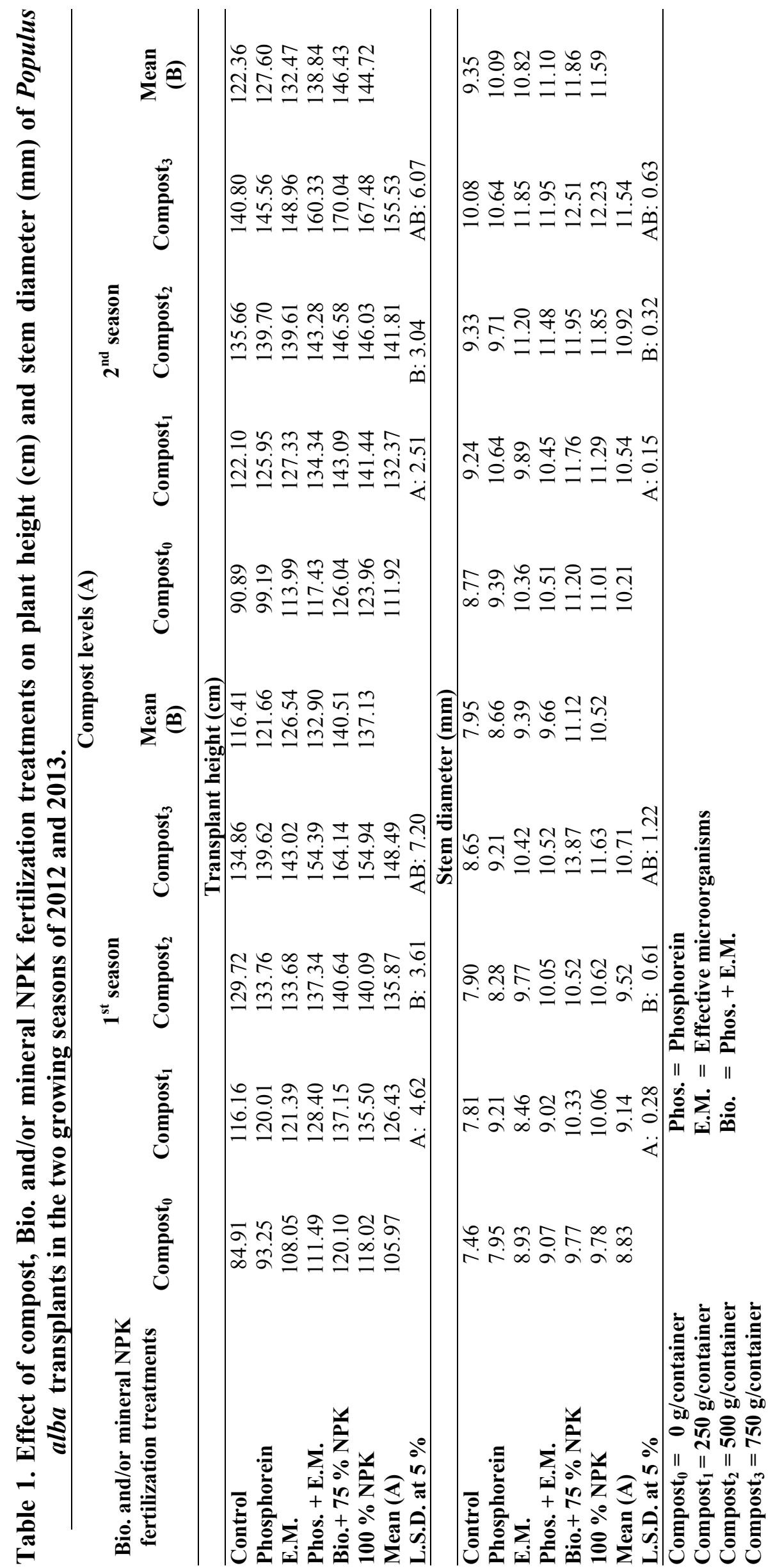




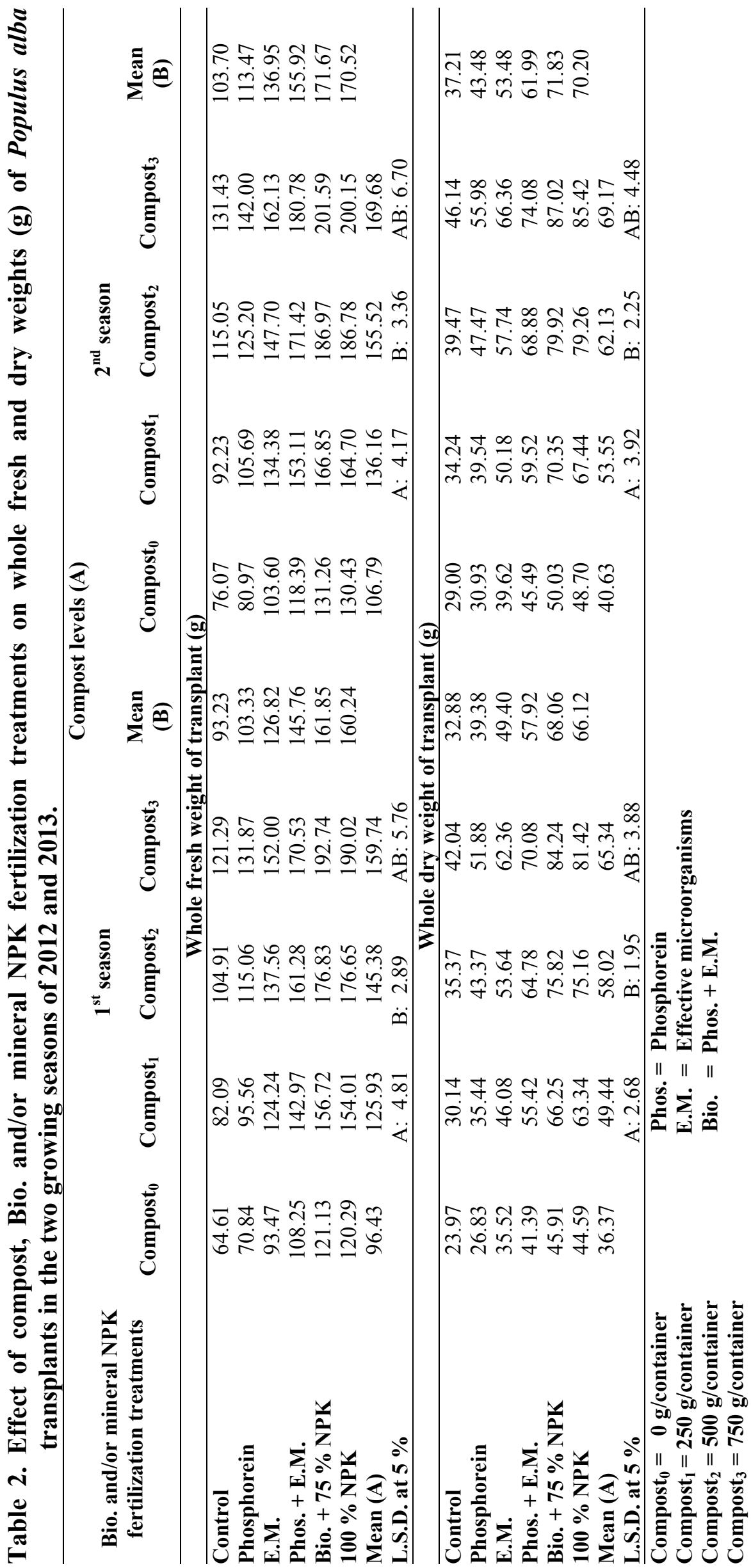


and cell division, more carbohydrates and dry matter accumulation (Nijjar, 1985).

Data presented in Tables (1 and 2) indicated that transplant height, stem diameter, fresh and dry weights of whole plant/transplant were significantly increased, in both seasons, due to the use of all treatments of Bio. and/or mineral NPK fertilization treatments in comparison with unfertilized control. The treatment of mixture of biofertilizers (phosphorein and E.M.) $+75 \%$ NPK dose followed by mineral NPK (full dose) seemed to be more effective than the other four treatments. However, no significant differences were detected between such two superior treatments for the four vegetative growth characters in the two seasons. These findings go parallel with those of Ahmed et al. (2005) on Populus nigra; Moustafa (2008) on Chorisia speciosa and Abdou and Ashour (2012) on jojoba seedlings regarding the effect of biofertilizers. Meantime, Badran et al. (2003) on Acacia saligna; Abd El-Dayem (2003) on Taxodium distichum; Ali (2005) on Sterculia diversifolia and El-Morshedy (2007) on Terminalia arjuna, found that NPK treatments increased seedling height, stem diameter and fresh and dry weights of such plants.

The stimulatory effect of biofertilizers and/or mineral NPK may be attributed to the role of NPK on plant physiological processes (Devlin, 1975). Also, biofertilizers increase soil available $\mathrm{N}$ and $\mathrm{P}$, as well as, other nutrient elements, consequently increase formation of metabolites which encourage the plant vegetative growth. In addition to gibberellins and auxins which came as a result from inoculation of biofertilizers, that encourage the cell division and cell enlargement (Spernat, 1990 and Hauka, 2000).

The interaction between compost and Bio. and/or mineral NPK fertilization treatments was significant in the two seasons for the four characters. The highest values were obtained due to supplying Populus alba with compost $_{3}$ in combination with Bio. + $75 \%$ NPK dose or mineral NPK (full dose).

\section{2- Root growth characters:}

Data presented in Tables (3 and 4) revealed that the used of compost treatments had pronounced significant effects on the length of main root, fresh and dry weights of root system when compared with untreated ones in the two growing seasons. The highest values of the four parameters resulted from the treatment of compost $_{3}$ followed by compost $_{2}$ then compost $_{1}$. The differences among the different treatments reached the significant level $(5 \%)$ in all cases in the two seasons.

The increase in root growth may be due to the mode of action of organic manure in improving the physical characters of the soil that facilitate the roots penetration. Also, nutrients, cytokinins and vitamins from analyzed organic manure have an improving effect on plant growth, consequently weight of root system (Abo El-Fadl et al., 1968). Similar results were obtained by Saleh (2000) on Ficus benjamina, El-Sayed and Abdou (2002) on Khaya senegalensis; Abdou et al. (2003) on Delonix regia and Ashour (2010) on jojoba seedlings.

Data presented in Tables (3 and 4) showed that all used fertilization treatments significantly increased, main root length, roots fresh and dry weights/transplant over the control in both seasons. The highest values of main root length, roots fresh and dry weights and stem/root ratio were resulted from the treatments of Bio. + 75\% NPK dose and mineral NPK (full dose).

These results may be referred to that the different fertilizers increased partitioning to perennial tissues as coarse roots. Also, they increase the biosynthesis and metabolites which consequently increased carbohydrates accumulation in the roots.

In agreement with these results concerning biofertilizers were those of Abdou et al. (2007) and El-Tayeb and ElSayed (2010) on Ficus spp. and TwumAmpofo (2008) on Gliricida sepium. 


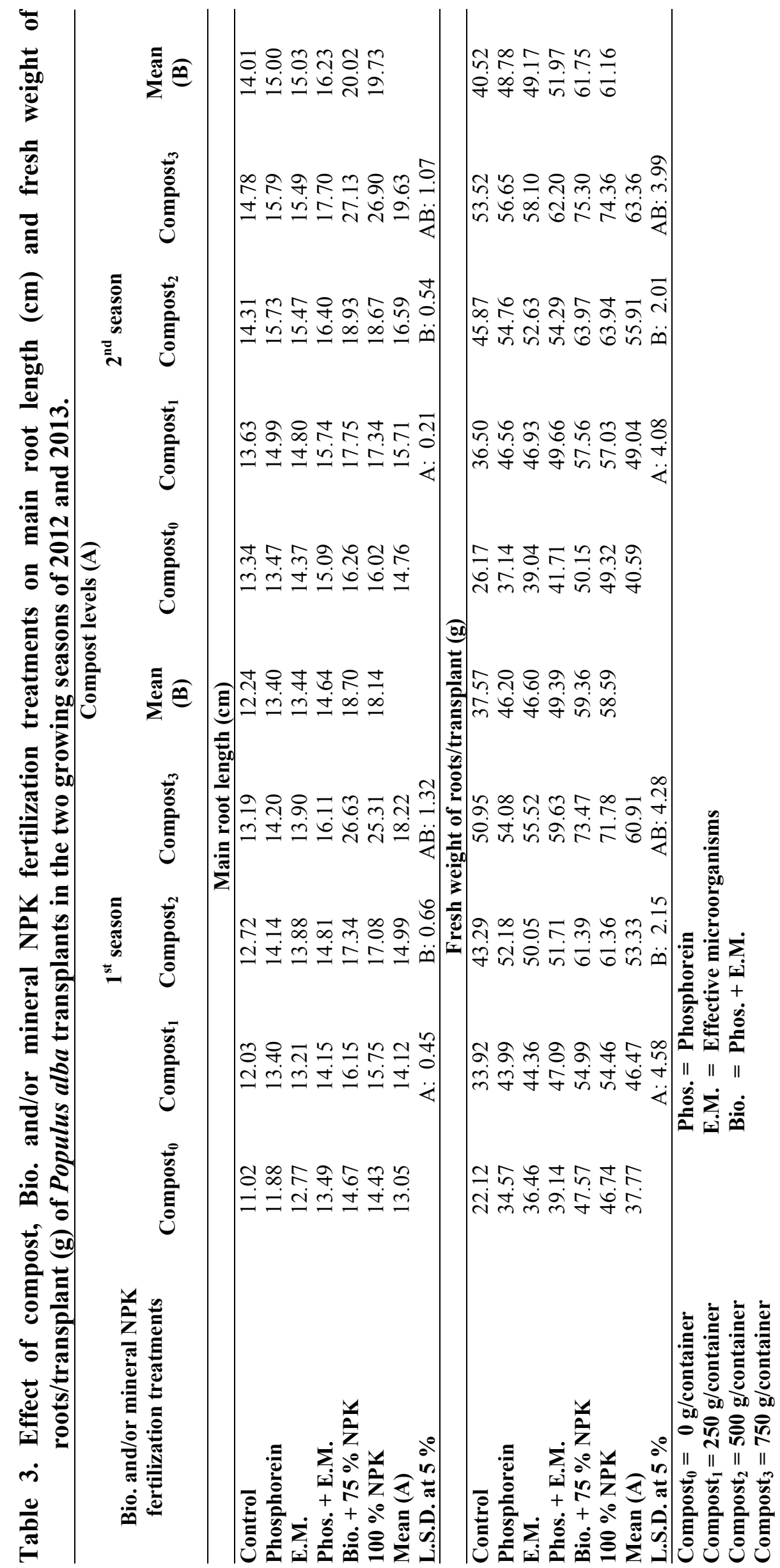


M.A.H. Abdou and T.I.E. Ibrahim

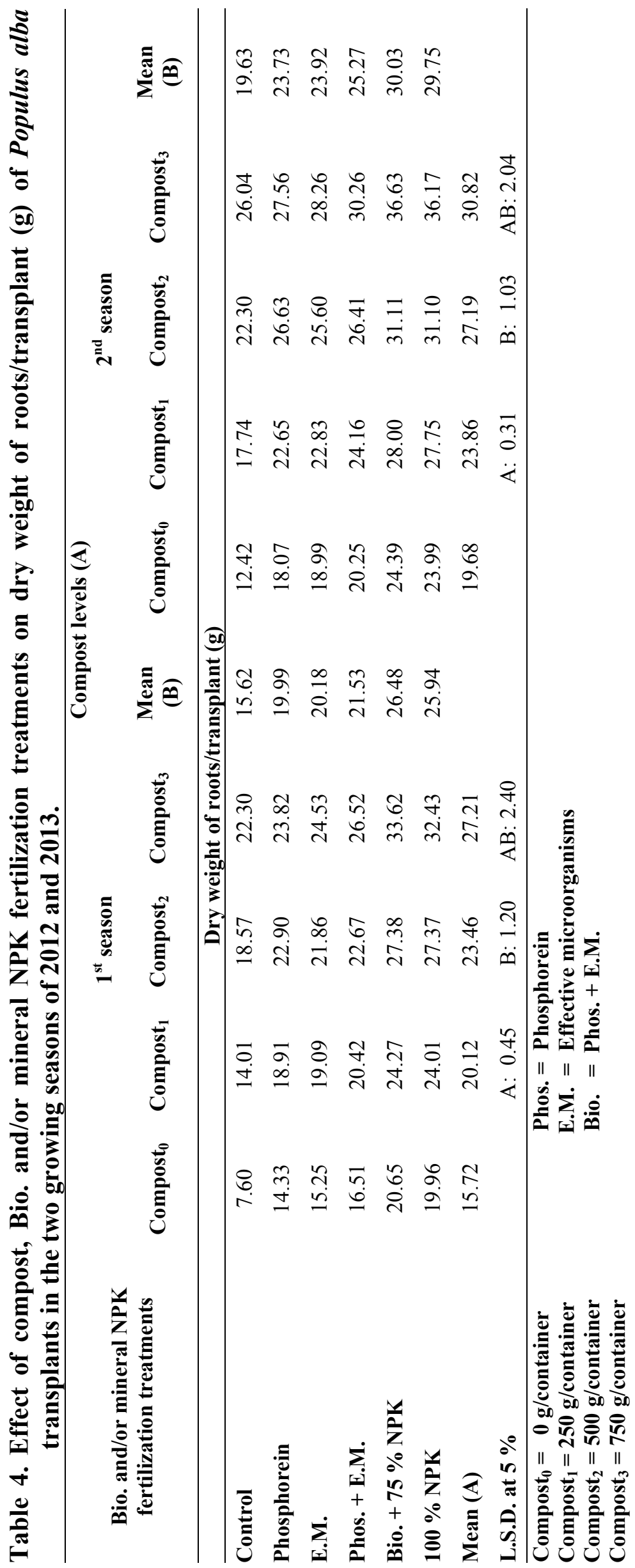


However, the role of mineral NPK was obtained by El-Morshedy (2007) on Grivellea robusta and Terminalia arjuna and Amin (2013) on Pinus radiata and Robinia pseudoacacia.

The interaction between main and sub plot treatments was significant for main root length and roots fresh and dry weights in both seasons. The tallest and heaviest weights of roots were obtained by adding compost $_{3}$, (750 g/container) in combination with Bio. $+75 \%$ NPK dose or with only mineral NPK (full dose) as clearly shown in Tables (3 and 4). In this concern, Abdou and Ashour (2012) stated that organic manure in combination with Bio.+ reduce the dose of mineral NPK resulted in the heaviest roots weight which was equal to that from recommended dose of mineral NPK in combination with organic manure.

\section{3- Chemical constituents:}

\section{a. $N, P$ and $K \%$ :}

Data presented in Tables (5 and 6) indicated that the three compost fertilization treatments had pronounced effects on $\mathrm{N}, \mathrm{P}$ and $\mathrm{K} \%$ in the dry leaves during the two growing seasons when compared with the control. The highest N, P and K percentages were resulted from the treatment of high level of compost (750 g/container).

This result may be referred to the increment of $\mathrm{N}, \mathrm{P}$ and $\mathrm{K}$ in the root zone as a result of adding organic manure thereby improved the uptake of nutrient elements (Awad et al., 2003).

Similar results were obtained by Ali et al. (2002) and Ahmed et al. (2006) on Populus nigra; Wroblewska et al. (2009) on Salix purpurea and Ahmadloo et al. (2012) on cypress seedlings.

It is obvious from data presented in Tables (5 and 6) that the application of either phosphorein or Effective microorganisms whether in mixture or separately, Bio. $+75 \%$ NPK dose and mineral NPK (full dose) resulted in a significant increase in $\mathrm{N}, \mathrm{P}$ and $\mathrm{K} \%$ in the dry leaves compared to the control in both seasons. The highest values of $\mathrm{N}, \mathrm{P}$ and $\mathrm{K} \%$ were recorded for the treatment of mineral NPK (full dose), followed by the treatment of Bio. $+75 \%$ NPK dose without significant differences between such two superior treatments in case of $\mathrm{P} \%$ in both seasons and $\mathrm{N} \%$ in the second season.

The positive effect of mineral NPK and biofertilizers on $\mathrm{N}, \mathrm{P}$ and $\mathrm{K} \%$ may be due to the increment of NPK elements in the root zone from application of NPK and inoculation by bacteria which, it turn account on the N, P and K uptake (Devlin, 1975 and Hauka, 2000).

This was in accordance with the previous results on poplar reported by Ali et al. (2002); Ahmed et al. (2005), Coleman et al. (2006) and Balasus et al. (2010) regarding the effects of NPK. Moreover, Ahmed et al. (2005) on Populus nigra; Moustafa (2008) on Chorisia speciosa; Umashankar et al. (2012) on silver oak and Abdou and Ashour (2012) on jojoba seedlings concluded that biofertilizers plus mineral NPK fertilization treatments increased the percentages of $\mathrm{N}, \mathrm{P}$ and $\mathrm{K}$.

The interaction was significant for $\mathrm{N}, \mathrm{P}$ and $\mathrm{K} \%$ in both seasons. The highest values were obtained from the treatment of compost $_{3}$ in combination with mineral NPK followed by the treatment of compost $_{3}$ in combination of Bio. $+75 \%$ NPK dose.

\section{b. Total chlorophylls:}

The content of total chlorophylls in the fresh leaves of popular was significantly promoted due to compost treatments, in the two seasons, in comparison with those of untreated plants as shown in Table (6). Compost $_{3}$ gave the highest values for total chlorophyll in both seasons followed by compost $_{2}$ and then compost 1 . This result may be attributed to the increase in nutrient elements and/or positive role of $\mathrm{Mg}$ that reflect on the chlorophyll content.

In harmony with these results regarding organic fertilization treatments were those reported by Abass (2003) on Rosa hybrida; 
M.A.H. Abdou and T.I.E. Ibrahim

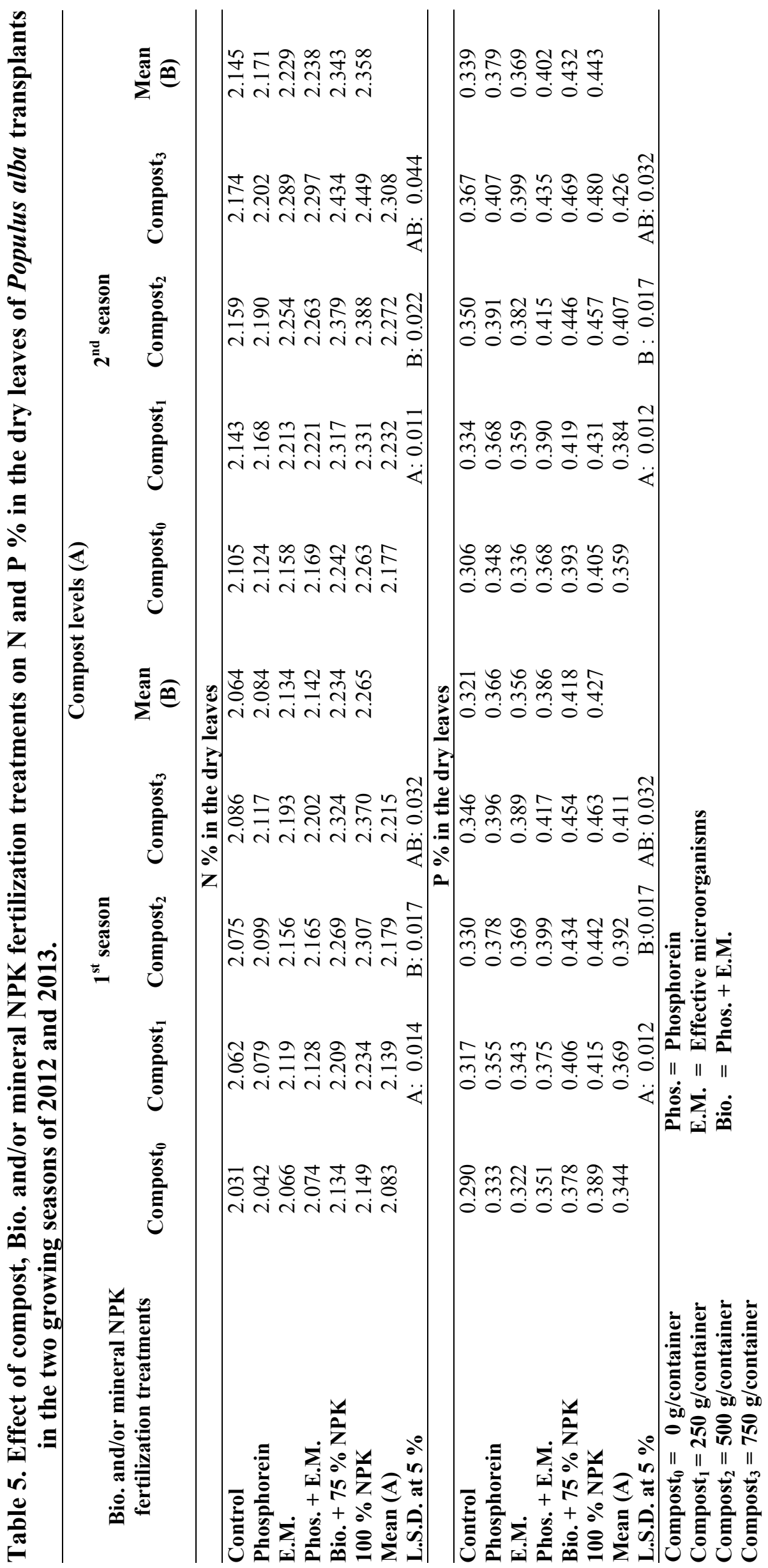




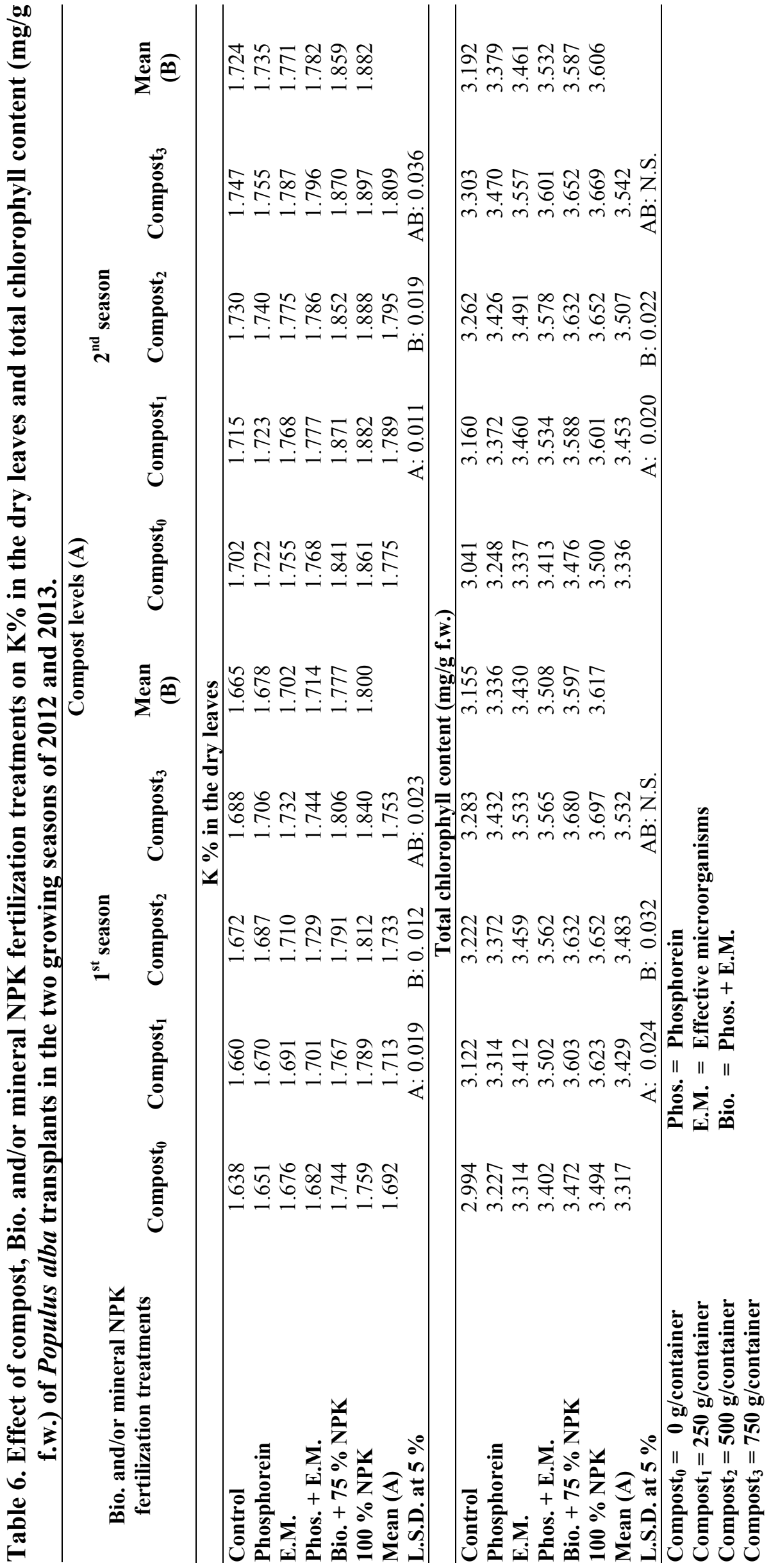


Sakr (2005) on senna plants; El-Khateeb et al. (2006) and Abdou et al. (2007) on Ficus spp.

In relation to the influence of different biofertilizer and/or mineral NPK treatments, total chlorophylls content was promoted in the two seasons (Table, 6). Obtained data show that the differences between any fertilization treatment and control were statistically significant. The highest contents of chlorophyll were obtained due to the treatment of mineral NPK (full dose) or the treatment of Bio. $+75 \%$ NPK dose.

This result may be attributed to the increase in nutrient elements which came as a result from adding NPK or inoculating with bacteria that reflect on chlorophyll content. Similar results were obtained by Ashour (2010) on jojoba seedlings.

The interaction between compost and Bio. and/or mineral NPK fertilization treatments was not significant in both seasons.

\section{REFERENCES}

Abass, R.A. (2003). Effect of the natural and synthetic soil conditioners on the growth of Rosa hybrida cv. Queen Elizabeth. J. Adv. Agric. Res., 8(4):673-688.

Abd El-Dayem, A.M. (2003). Effect of fertilization treatments in Taxodium distichum seedlings grown in alkali soil. For. Bce Manage. 33134:531-541 (c.f. Tree Physiology 16:307-313).

Abdou, M.A.H.; Ahmed, E.T. and Attia, F.A. (2003). Response of Delonix regia, RAF. transplants to fertilization with sewage sludge and inoculation with phosphorein and VA-mycorrhizal fungi. Proc. $1^{\text {st }}$ Conf. Egypt and Syr. El-Minia Dec. 8-11, 2003.

Abdou, M.A.H. and Ashour, R.M. (2012). Physiological studies on jojoba plants. Proc. Minia Inter. Conf. for Agric. and Irrig. In the Nile Basin countries. $26^{\text {th }}$ $29^{\text {th }}$ March 2012, El-Minia, Egypt.
Abdou, M.A.H.; Badran, F.S.; Aly, M.K. and Ashour, R.M. (2007). Physiological studies on the propagation of Ficus elastica var. Decora by aerial layering. Proc. the $1^{\text {st }}$ Inter. Conf. Desert Cultivation, Problems \& Solutions, Minia Univ., 27 - 29 March, 2007.

Abo El-Fadl, M.; Rizk, S.G.; Abdel - Ghani, A.F.; El-Mofty, M.K.; Khadr, M.F.A.; Shehata, S.M. and Farag, F.A. (1968). Utilization of water hyacinth as an organic manure with special reference to water - borne helminthes. J. Microbial, ARE, 3 (1): 27 - 34.

Ahmadloo, F.; Tabari, M.; Yousefzadeh, H.; Kooch, Y. and Rahmani, A. (2012). Effects of soil nutrient on seedling performance of Arizona cypress and medite cypress. Annals of Biological Research, 3(3):1369-1380.

Ahmed, A.A.; Ali, A.F. and Dakhly, O.F. (2005). Response of Populus nigra seedlings to Azotobacter vinelandii transformant isolates and nitrogen fertilization. Proc. $6^{\text {th }}$ Arabian Conference for Horticulture, Ismailia, Egypt. p:138-150.

Ahmed, A.A.; Ali, A.F. and Taha, R.A. (2006). A compartive study between two poplar species grown in sandy calcareous soils using certain compost levels. Minia J. of Agric. Res. \& Develop., 26(4):663681.

Ali, A.F.; Ahmed, A.A. and Mahmoud, M.R. (2002). Response of Populus nigra seedlings grown in sandy calcareous soil to some organic fertilizers and nitrogen level treatments. Proc. Minia $1^{\text {st }}$ Conf. for Agric. \& Envir. Sci., Minia Egypt, 22(2A):377-392.

Ali, N.F.M. (2005). Effect of Some Agricultural Treatments on The Growth and Chemical Composition of Sterculia diversifolia seedlings. M.Sc. Thesis, Fac. Agric., Minia Univ. 
Amin, M.A. (2013). Study of the fertigation requirement for some woody trees. J. of Applied Sci. Res., 9(1):281-293.

Ashour, R.M. (2010). Response of Jojoba Plants to Some Organic and Biofertilization Treatments. Ph.D. Thesis, Fac. of Agric., Minia Univ.

Awad, Y.H.; Ahmed, H.A. and El - Sedfy, O.F. (2003). Some chemical properties and NPK availability of sandy soil and yield productivity as affected by some soil organic amendments. Egypt. J. Appl. Sci., 18(2):356-365.

Badran, F.S.; Abdou, M.A.; Aly, M.K.; Sharaf, El-Deen, M.N. and Mohamed, S.H. (2003). Response of sandy soil grown Acacia saligna seedlings to organic bio- and chemical fertilization and IAA treatments. Proc. $1^{\text {st }}$ Egyptian Syrian Conf. for Agric. and Food in the Arabian Nations, Minia Univ., Minia, Egypt, December, 8-11.

Balasus, A.; Kern, J.; Bischoff, W.; Muller, M. and Scholz, V. (2010). Effect of mineral fertilization on Populus nigra. Bulletin Article; Conferernce Paper Julius - Kühn - Archiv 2010 No 428 p:479-480.

Ball, J.; Carle, J. and Del Lungo, A. (2005). Contribution of poplars and willows to sustainable forestry and rural development. Unasylva 221, Vol. 56.

Bradshaw H.D.; Ceulemans R.; Davis J. and Stettler, R. (2007). "Emerging model systems in plant biology: poplar (populus) as a model forest tree". Journal of Plant Growth Regulation. 10:306-313.

Coleman, M.; Tolsted, D.; Nichols, T. and Edward, G. (2006). Post-establishment fertilization of Minnesota hybrid poplar plantations. Biomass and Bioenergy, 30:740-749.

Devlin, R.M. (1975). Plant Physiology. $3^{\text {rd }}$ Ed. Affiliated East West Press, New Delhi. Chap. 10, 11:159-205.
El-Kayal, W.E. (1996). Response of Seedlings of Five Tree Species to Applications of Sewage Sludge and Chemical Fertilizer on Two Soil Types. M.Sc. Thesis, Fac. Agric., Alex. Univ.

El-Khateeb, M.A.; El-Maadawy, E.E. and El - Attar, A.B. (2006). Effect of growing media on growth and chemical composition of Ficus alii, plants. Annals of Agric. Sci., Moshtohor, 44(1):175193.

El-Morshedy, R.A.M. (2007). Studies on Fertilization of Some Woody Transplants. M.Sc. Thesis, Fac. Agric., Kafr El - Sheikh Univ.

El-Quesni, F.E.M.; Hashish, Kh. I.; Kandil, M. and Mazhar, A. (2013). Impact of some biofertilizers and compost on growth and chemical composition of Jatropha curcas, L. World Applied Sci. J., 21(6):927-932.

El-Sayed, A.A. and Abdou, M.A.H. (2002). Response of Khaya transplants to some soil media and biofertilization treatments. Ann. of Agric. Sci., Moshtohor, 40(4):2233-2245.

El-Tayeb, H.F. and El-Sayed, B.A. (2010). Response of Ficus binnendykii (Miq.) Miq.cv. "AMSTEL QUEEN" transplants to some biofertilizers. Mesponse $\mathrm{J}$. of Agric., 38(1):1-6.

Gangoo, S.A.; Mughal, A.H. and Makaya, A.S. (1997). Fertilizer response by two species of poplars (based) on initial growth parameters. Indian-Forester, 123(3):240-244.

Hart, J.B.; Jr. and Nguyen, P.V. (1994). Soil, groundwater, and plant resources in sludge-treated bigtooth aspen sapling ecosystems. Journal of Environmental Quality, 23:1257-1264.

Hauka, F.I.A. (2000). Impact of dual inoculation with Rhizobium sesbania and Vesicular-Arbuscular Mycorrhiza on growth and nutrition of Sesbania aegyptiaca in a calcareous soil. J. Agric. Sci., Mansoura Univ., 25(10):6465-6480. 
Kohan, S.; Kosice, S. and Vyskumna, S. (2000). Effect of fertilization on the production and health of poplar 1-214 (Populus $\times$ Euroamericana cv. 1-214) in intensive plantations. J. of Forest Sci., 46(7):325-330.

Liu, D.; Kang, M.; Letort, V.; Xing, M.; Yang, G.; Huang, X.; and Cao, W. (2009). Preliminary Functional-Structural Modeling on Poplar (Salicaceae). Plant Growth Modeling, Simulation, Visualization and Applications (PMA), 2009 Third International Symposium on 9-13 Nov. 2009. pp: 49-52.

Moran, R. (1982). Formula determination of chlorophyllous pigment extracted with $\mathrm{N}$ -N-dimethyl-formamide. Plant Physiol., 69:1376-1381.

Moustafa, H.E.B. (2008). Influence of Some Growth Media, Biofertilization and Antioxidants on The Growth of Chorisia speciosa Tree Seedlings. Ph.D. Thesis, Fac. Agric., Minia Univ. Egypt.

MSTAT-C (1986). A Microcomputer Program for the Design Management and Analysis of Agronomic Research Experiments (version 4.0), Michigan State Univ., U.S.A.

Nijjar, G.S. (1985). Nutrition of Fruit trees. Mrs. Usha Raj Kumar for Kalyani publishers, New Delhi, p: $10-52$.

Page, A.L.; Miller, R.H. and Kenney, D.R. (1982). Methods of Soil Analysis, Part II. Amer. Soc. Agron. Inc, Madison, Wisconism, USA.

Rajeshkumar, S.; Nisha,M.; Prabu, P. and Selvaraj, T. (2009). Interaction between Glomus geosporum, Azotobacter chroococcum and Bacillus coagulans and their influence on growth and nutrition of Melia azedarach, L. Turk J. Biol., 33:109-114.

Sakr, W.R.A.S. (2005). Effect of Organic and Biofertilization on Growth and Active Constituents Production of Senna
Plants. Ph.D. Thesis., Fac. Agric. Cairo Univ.

Saleh, S.I.I. (2000). Effect of different planting media on the growth and chemical composition of Ficus benjamina "Starlight" plants. (C.F. ElKhateeb et al., 2006).

Spernat, M. (1990). Nitrogen Fixing Organisms, P.S. Chapman and Hall London.

Tisdale, S.L.; Nelson, W.L. and Beaton, I.D. (1985). Soil Fertility and Fertilizers. $4^{\text {th }}$ Ed. Macmillan Publishing Company, A division of Macmillan, Inc., New York, $754 \mathrm{pp}$.

Tripathi, A.M.; Trnka, M.; Fischer, M.; Fajman, M. and Zalud, Z. (2012). Estimation of above ground woody biomass of SRC hybrid poplar clone J105 in different fertilizer treatments in Czech-Moravian Highland. Conference: Mendel Net 2012, Brno (CZ), 2012-11$21 / 2012-11-22$

Twum-Ampofo, K. (2008). Growth response of Gliricidia sepium (Jacq.) Walp to inoculation with different rhizobium bacteria. J. of Sci. and Tech., 28(2):5465 .

Umashankar, N.; Venkateshamurthy, P.; Krishnamurthy, R. and Satish, K.M. (2012). Effect of microbial inoculants on the growth of silver oak (Grevillea robusta) in nursery conditions. Inter. J. of Environ. Sci. and Develop., 3(1):72-76.

Wroblewska, H.; Kozik, E. and Czajka, M. (2009). Content of macro and microcomponents in willow grown in substrates with composts of post - use wood waste. Folia Forestalia Polonica Series B, Issue 40, 23-30.

Zabek, L.M. (1995): Optimum Fertilization of Hybrid Poplar Plantations in Coastal British Columbia (Thesis). University of British Columbia, 84 pp. 


\section{استجابة شتلات الحور الأبيض للتسميد العضوي والحيوي والمعلني النتروجيني الفوسفوري البوتاسي}

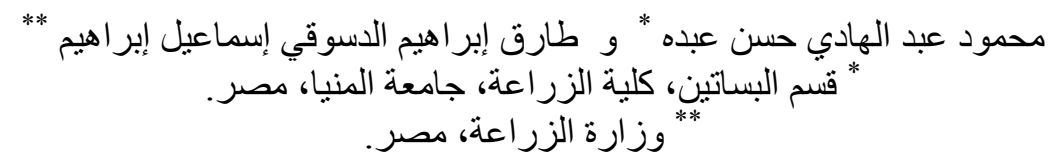

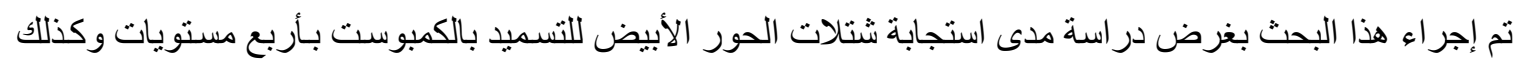

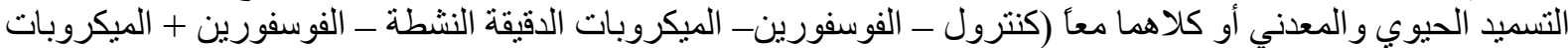

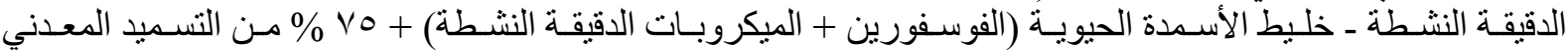

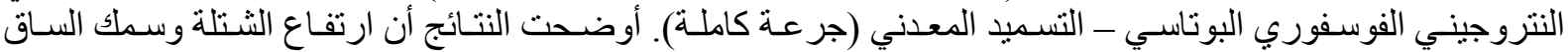

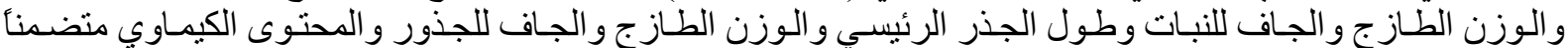

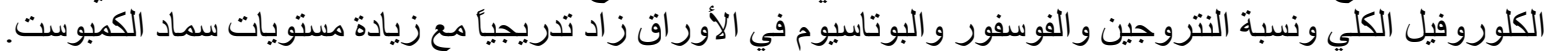

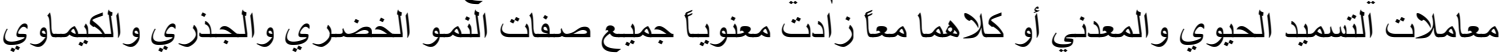

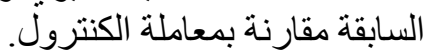

وكانت معاملة خليط الأسمدة الحيوية + Vo \% من التسميد المعدني ثم التسميد المعدني بالجر عـة الكاملة أكثر تأثير آ في هذا الثأن.

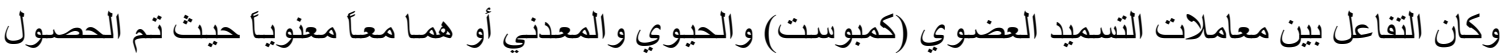

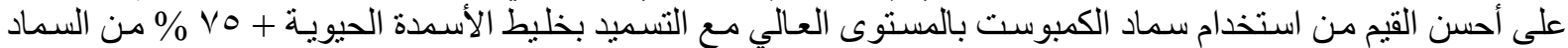
المعدني أو مع التسميد المعدني بالجر عة الكاملة. 
